\title{
APPLYING THE CONCEPT OF DIVERSITY MANAGEMENT IN ORGANISATIONS IN THE CZECH REPUBLIC AND THE SLOVAK REPUBLIC - A RESEARCH SURVEY
}

\author{
Dana EGEROVÁa, Milena JIŘINCOVÁ ${ }^{b}$, Drahoslav LANČARIČc, Radovan SAVOV \\ ${ }^{\mathrm{a}, \mathrm{b}}$ Faculty of Economics, University of West Bohemia, Husova 11, Pilsen, Czech Republic \\ ${ }^{c, \mathrm{~d}}$ Faculty of Economics and Management, Slovak University of Agriculture in Nitra, \\ Tr. Andreja Hlinku 2, Nitra, Slovak Republic
}

Received 12 October 2012; accepted 01 January 2013

\begin{abstract}
The paper deals with the implementation of diversity management in the Czech and Slovak organizations. The aim of the research was to find out how the concept of diversity management is accepted and applied in the Czech and Slovak companies. The scale questionnaire of the author's own construction was used for data collection. The questionnaire contained apart from the introductory classification items 25 items divided into three thematic areas: the field of inclusion and justice, the field of diversity management implementation and the field of benefits resulting from implementing diversity management. The statistically significant differences and dependencies that emerged among items in the questionnaire were examined by Kruskal-Wallis test and other statistical methods. The research survey revealed that respondents' answers were significantly affected by factors such as the seat of the company and the working position of the respondent. The respondents from the Slovak Republic generally perceive issue of diversity management more positively compared with respondents from the Czech Republic. Also the managers perceive issue of diversity management more positively compared with employees. The research survey identified partially the existing state of implementing the concept of diversity management in organizations in the Czech and Slovak Republics.
\end{abstract}

Keywords: diversity, diversity management, inclusion, justice, implementation, benefits, survey.

Reference to this paper should be made as follows: Egerová, D.; Jiřincová, M.; Lančarič, D.; Savov, R. 2013. Applying the concept of diversity management in organisations in the Czech Republic and the Slovak Republic - a research survey, Technological and Economic Development of Economy 19(2): 350-366.

JEL Classification: F23, M10, M12, M19, M53.

Corresponding author Dana Egerová

E-mail: egerova@kpm.zcu.cz 


\section{Introduction}

As a result of general changes in the society, demographic development and globalization of the labour market diversity management have become ever more important. To survive in the current highly competitive and global business environment, organisation must pay attention to the issue of diversity and make good use of the potential that diversity has on offer.

The basis of diversity management concept can be seen in the natural substance of diversity existing in the human society where diversity of people from the point of their age, gender, race, ethnicity, mental and physical abilities, sexual orientation and other characteristics is a natural thing (Eger et al. 2009; Hubbard 2004a). Risberg and Soderberg (2008) define diversity as "a mix of differences, similarities, and tensions that can exist among the elements of a collective mixture". Diversity or heterogeneity may be understood from the point of view of certain criteria or dimensions. In this sense we distinguish between primary and secondary diversity (Hubbard 2004a; Süß, Kleiner 2008). According to Bedrnová and Nový (2007) factors such as age, ethnicity, gender, mental and physical abilities, race and sexual orientation belong to the basic characteristics of primary diversity. Secondary diversity includes mainly factors such as socio-economic status, education, religion, geographical affiliation and marital status (Sweetman 2004). Some authors (Eger et al. 2009; Bedrnová, Nový 2007) mention other characteristics such as work experience, style of communication, style of work, organisation roles and standards. The primary diversity characteristics cannot be changed while those of secondary diversity can. For the purposes of our research survey namely the dimensions of primary diversity have been used. The importance of the given dimensions is significantly determined by the environmental factors (cultural, social and demographic) in which the organisation operates (Durska 2009). Wishing to be effective with diversity organisation must identify the key dimensions of diversity (Thomas 2006, 2010). Identification of key diversity dimensions enables the organisation to apply strategies, programmes and techniques for its management at all the organisation levels and it can also provide a strategic advantage.

The notion of diversity management has a broader meaning than the notion of diversity itself. The concept of diversity management dates back to 1980s but it was not until a few years ago that it spread further to the field of the management theory and practice. It is then a relatively new phenomenon in management theory and practice and a new field in management, which keeps on developing.

Various definitions and interpretations of diversity management are given in management literature. If diversity is seen as a mix of differences and similarities that are used by the organisation management to meet their organisation objectives, diversity management can be defined ,as a process of planning for, organizing and supporting these collective mixtures in a way that adds a measurable difference to organisational performance" (Hubbard 2011). At the same time we can define it as an active and conscious reaction of strategic, value-oriented, communicational and managing process which is future-oriented and consists in acceptance and in using particular differences and similarities as a potential driving force in organisations (Keil et al. 2007). Consider this definition the concept of diversity management could be seen as the ways how to not only respect diversity but also make use of it and understand it as a competitive advantage based on better use of the potential of each individual. 
The current concept of diversity management perceives diversity as a matter of the entire organisation, as a business strategy focused on using the potential of the organisation's members with the aim to achieve a competitive advantage. In this context the application of diversity management is closely connected with achieving the organisation vision and mission, with its strategic management and also with the human resource management (Egerová 2012).

Effective implementation of the diversity strategy provides many benefits to organisation. Literature (Hubbard 2004b, 2011; Ilmakunnas, P., Ilmakunnas, S. 2011; Risberg, Soderberg 2008; Thomas 2010) most often mentions improved quality and effectiveness of the workforce, increased creativity, innovativeness and flexibility in the organisation, improved organisation image, positive changes in the organisational structure, better possibilities of recruiting and retaining talented workers, improved relationships with customers, strengthening market positions, all of which, as a result, bring the organisation a competitive advantage. According to the survey (European Comission 2008) the following benefits were indicated as the most significant by small and medium sized businesses - attracting, recruiting and retaining best talents (60\% of respondents), increasing creativity/innovation (45\%), increasing client's loyalty (40\%), reducing wasted time (35\%), increasing company profits (35\%) and accessing new markets (35\%).

Experience has shown that organisation's approaches to diversity or diversity management vary significantly. From organisations implementing the strategy of diversity management effectively and where this strategy become part of the overall company strategy, through organisations where some principles and strategies of diversity management are implemented, down to organisations that do not consider introducing the strategy of diversity management desirable and their activities are only limited to complying with legal norms. Understanding the existing state in the given field is a significant starting point for further development and practical implementation of the concept of diversity management.

\section{Methodology}

The research survey was implemented with the aim to find out how the concept of diversity management is accepted and implemented in the environment of the Czech and Slovak companies. The theoretical survey about the issues to be solved was created on the basis of the studies of the printed and non-printed information sources relevant to the topic of diversity management. When processing them the methods of analysis, synthesis, deduction, induction and comparison were used. Selective survey was used as a method of data collection. According to Rimarčík (2007) the selective survey means that the necessary data are only surveyed with a part of the units of the basic file, i.e. with the units that were chosen from the basic file in a certain way. The selective file was determined randomly. The author Jurčová (2005) states it is an incomplete statistical survey that serves collecting and processing data concerning some determined characteristics of the given basic file. A scale questionnaire of the author's own construction was used as a tool of collection that apart from the introductory classification items (legal form, number of employees, proportion of foreign capital, field of activities, work position of the respondent and the company seat) contained 25 items divided into three topics, namely the field of inclusion and justice, the field of the diversity management 
implementation and the field of benefits resulting from the implementation. The individual items of the questionnaire were scaled. Likert scale from 1 to 7 was used, where: number 1 corresponded to the absolute consensus of the respondent with the statement in the wording of the item (formulated as a positive statement), and number 7 , on the contrary, to the absolute disagreement of the respondent. Number 4 expressed his/her irresolute attitude and the additional number 8 enabled the respondent not to comment on a given item. All such "answers" were excluded from further processing. The questionnaire was partly distributed in person and partly electronically by means of an online form of the Google documents system. On the whole 355 respondents from the Czech and the Slovak Republics participated in the research (also thanks to the personal distribution of questionnaires which provided for high returnability). Each respondent represents one business subject.

Because the questionnaire did not consist of dichotomized items, the reliability was verified by means of Cronbach's alpha. According to Rimarčík (2007) the assessment of scales is based on examining correlations between the individual items or measurements in relation to the variability of the items. The values of Cronbach's alpha 0.7 and more mean sufficient internal scale consistence. The method of split-half measurement instrument was used as the second method of verifying the reliability. This method is based on the fact that the items of the questionnaire are split into two halves. One half is formed by the results of the pair items and the other half by the results of the non-pair items. The scores for the pair and non-pair items are calculated separately. The results of the pair and non pair items are then correlated.

The validity (construction) was verified by means of a factor analysis. According to Hebák (2005) the factor analysis is a multidimensional statistical method which focuses on creating new variables and tries to reduce the range of data with the least possible data loss.

Owing to the character of the collected data (ordinal variables) non-parametric statistical methods were used. To verify the existence of statistically significant differences between the individual groups of respondents (depending on a particular factor, see classification units) the Kruskal-Wallis test was used. According to the authors Pavelka and Klímek (2000) the Kruskal-Wallis test is a non-parametric parallel of a simple classification of the dispersion analysis (dispersion analysis for one factor). It is a direct generalisation of the Wilcoxon two sample test (when $\mathrm{k} \geq 3$ ). According to Rimarčík (2007) the aim of the test is to find whether the differences of the medians found in the sample of the individual groups are statistically significant (there is a relationship between the variables) or whether these are coincidental (there is no relationship between the variables). A null statistical hypothesis with parity of all the medians is tested. If the p-value is lower than the chosen level of significance (traditionally $5 \%=0.05$ ), the null hypothesis is rejected. This means that the difference between at least one pair of the medians calculated from the sample is too big to be a result of only random selection, i.e. it is statistically significant - there is a relationship between the variables. If the p-value is equal or higher than the chosen level of significance, the null hypothesis cannot be rejected. This means that the difference between each pair of the medians calculated from the sample can only be a result of random selection, i.e. it is not statistically significant there is no relationship between the variables. In case the Kruskal-Wallis test confirmed the existence of a statistically significant difference, suitable methods of the non-parametric correlation were applied to explain the difference in more detail. These methods were used if, 
as Jurčová (2005) states, the random selection did not stem from the two-dimensional normal division or if it contained some remote observations, which was the case of our research. According to Rimarčík (2007) the Spearman coefficient is the most frequently used ordinal coefficient which can be calculated from the formula used for the calculation of the Pearson coefficient where instead of the original values their ordinal numbers are used. Therefore the Spearman correlation coefficient is difficult to interpret. Unlike Spearman coefficient, Kendall coefficient expresses the extent of dependency between two ordinal variables, i.e. it expresses the difference between the probability that the values of two variables are in the same order as opposed to the probability that the values are not in the same order. The values of both the non-parametric correlation coefficients do not equal and are not mutually comparable. Kendall's tau states values lower than Spearman's $\rho$. But in both the coefficients there is the same amount of applied information included in the analyzed values, and therefore they have, as far as the detection of the relationship is concerned, the same weight. Statistical software SPSS 17.0 was used for calculations.

\section{Verifying reliability and validity of the measurement instrument}

The reliability of the questionnaire was verified by means of the method described closer in Chapter 1. Table 1 summarizes the gained results.

Table 1. Reliability of used questionnaire

\begin{tabular}{lcccccc}
\hline & \multicolumn{2}{c}{ Cronbach`s Alfa } & \multicolumn{2}{c}{ Split-half } & Guttman & $\begin{array}{c}\text { Number of } \\
\text { items }\end{array}$ \\
\cline { 2 - 5 } & $\begin{array}{c}\text { Cronbach's } \\
\text { Alpha }\end{array}$ & $\begin{array}{c}\text { Cronbach's Alpha Based } \\
\text { on Standardized Items }\end{array}$ & Equal & Unequal & & \\
\hline Inclusion and justice & 0.850 & 0.869 & 0.702 & 0.702 & 0.694 & 12 \\
\hline Implementation & 0.852 & 0.851 & 0.836 & 0.836 & 0.836 & 6 \\
\hline Benefits & 0.897 & 0.900 & 0.803 & 0.805 & 0.783 & 7 \\
\hline Total reliability & 0.921 & 0.924 & 0.764 & 0.764 & 0.763 & 25 \\
\hline
\end{tabular}

Source: own processing.

As it is obvious from Table 1, both the item and the overall variability (with the exception of Guttman coefficient in case of the field of inclusion and social justice) correspond to the recommended value 0.7 and in many cases even exceed it. With regard to the achieved results it is therefore possible to regard the reliability of the measurement instrument as sufficient.

The construction validity was verified by the factor analysis by means of the varimax rotation of factors. The suitability of applying the factor analysis was verified on the basis of KMO test and Bartlett's test of sphericity. The condition of the minimum number of respondents (150) was met. The results of both the testing statistical methods were satisfactory (In Bartlett's test $\mathrm{p}<0.05, \mathrm{KMO}>0.7$, the value reached was 0.895 .) The suitability of applying the factor analysis was confirmed. The factor analysis identified six background factors which altogether explained almost $70 \%$ of the total dispersion. Based on the correlation of factors with the individual items it was possible to identify the below factors:

- factor 1 - benefits of the implementation of diversity management;

- factor 2 - fair treatment of employees; 
- factor 3 - diversity of employees taken into account when assigning job tasks as well as respecting employees;

- factor 4 - active support of diversity policy;

- factor 5 - respecting equal opportunities when employing the staff;

- factor 6 - physical handicaps acceptance.

Based on identifying the factors fully corresponding to the questionnaire content we regard the construction validity of the measurement instrument as satisfactory.

\section{Characteristics of the sample}

The first six items of the questionnaire served as a possibility of more detailed characteristics of the sample from the point of legal form, number of employees, seat, the proportion of foreign capital and the sector of national economy in which the relevant business subject operates. The work position of the respondent was the sixth classification item. Tables 4-9 summarize the proportional representation of the individual categories of such units. On the whole, 355 respondents participated in the research, each of them representing one business subject. Limited liability companies $(50.7 \%)$ were the highest represented group, followed by joint stock companies (28.2\%). Together with the public business companies business companies accounted for $80 \%$ of the sample. The intervals of the number of employees corresponded to the typology of businesses according to their sizes as stated in Gozora (2005). The representation of the individual categories is relatively even when the biggest proportion is accounted for by the so called large businesses (with the number of employees more than 250), namely $32.1 \%$. Out of the total number of 353 respondents 200 stated they had the seats of their businesses in the Slovak Republic (56.3\%), 139 in the Czech Republic (39.2\%) and 14 businesses had their seats in neither of the two states (3.9\%). Two respondents did not give the seats of their businesses. According to the feedback gained from the respondents filling the item, mapping the proportion of foreign capital posed the biggest problem especially for the respondents in non-managerial positions. Not always they knew what the exact proportion of foreign capital in their company was, or, as the case may be, whether the proportion concerned the registered capital or the total property assets, and that is why the results gained in this item should not be taken too seriously as their reliability may not be absolute. Despite this fact it may be stated that the domestic companies, without any foreign capital, had the biggest representation (129). The second most numerous group was represented by companies with the proportion of foreign capital up to $20 \%(28.2 \%)$. From the point of the sector of national economy the most numerous group represented in the sample was formed by businesses of tertiary sphere, i.e. service sector (54.4\%). Businesses from the secondary, processing sector were represented by $23.9 \%$ respondents. Public sector had the lowest level of representation, with only $9.3 \%$. The proportion of managerial and non-managerial respondents was relatively even with managers representing $54.4 \%$ respondents and non-managerial employees $45.1 \%$. Two respondents did not give their work positions. Each of the classification items served as a factor on the basis of which the existence of the statistically significant differences in the attitudes of the respondents towards diversity management was inquired. 


\section{The influence of the factors on the attitudes of the respondents}

Each of the topics was tested on the basis of the above stated six factors. The results of the Kruskal-Wallis test are summarized in Tables 2, 10 and 16. In each of the fields the wording of the relevant items is also given, the reason being a clearer interpretation of the gained results. One star in with values of correlation coefficients means that the correlations are statistically significant, the level of significance being 0.05 ; two stars mean the correlations are statistically significant, the level of significance being 0.01 . With regard to the scale used in the questionnaire (lower values meaning consensus, higher values disagreement), which is reversed in comparison with a commonly used scale, it was necessary, when interpreting the extent of dependency closeness, also to observe the numerosity of possibilities with the individual units.

\subsection{The field of inclusion and justice}

This field consisted of 12 items whose wordings were as follows:

Item 1 The organization has "diversity policy" clearly defined.

Item 2 The organization pays attention to the fact that the principle of equal opportunities is respected when recruiting new employees. (Not only because of complying with the legal regulations).

Item 3 The organization actively supports the policy of employing physically handicapped job candidates.

Item 4 The organization actively supports the policy of employing older job candidates.

Item 5 The organization actively supports the policy of employing job candidates from other ethnicities.

Item 6 The organization actively supports employing women.

Item 7 Managers treat the employees fairly, regardless of their age.

Item 8 Managers treat the employees fairly, regardless of their gender.

Item 9 Managers treat the employees fairly, regardless of their ethnicity.

Item 10 Managers treat the employees fairly, regardless of their religion.

Item 11 Managers treat the employees fairly, regardless of their sexual orientation.

Item 12 Managers treat the employees fairly, regardless of their physical handicap.

Table 2. Field of inclusion and justice

\begin{tabular}{|c|c|c|c|c|c|c|c|c|c|c|c|c|}
\hline & $\begin{array}{c}\text { Item } \\
1\end{array}$ & $\begin{array}{c}\text { Item } \\
2\end{array}$ & $\begin{array}{c}\text { Item } \\
3\end{array}$ & $\begin{array}{c}\text { Item } \\
4\end{array}$ & $\begin{array}{c}\text { Item } \\
5\end{array}$ & $\begin{array}{c}\text { Item } \\
6\end{array}$ & $\begin{array}{c}\text { Item } \\
7\end{array}$ & $\begin{array}{c}\text { Item } \\
8\end{array}$ & $\begin{array}{c}\text { Item } \\
9\end{array}$ & $\begin{array}{c}\text { Item } \\
10\end{array}$ & $\begin{array}{c}\text { Item } \\
11\end{array}$ & $\begin{array}{c}\text { Item } \\
12\end{array}$ \\
\hline p-level Legal Form & 0.087 & 0.913 & 0.091 & 0.368 & 0.231 & 0.955 & 0.017 & 0.043 & 0.039 & 0.822 & 0.546 & 0.469 \\
\hline $\begin{array}{l}\text { p-level Number } \\
\text { of Employees }\end{array}$ & 0.030 & 0.517 & 0.006 & 0.293 & 0.005 & 0.598 & 0.286 & 0.172 & 0.600 & 0.409 & 0.391 & 0.383 \\
\hline p-level State & 0.025 & 0.003 & 0.204 & 0.057 & 0.103 & 0.002 & 0.008 & 0.002 & 0.069 & 0.011 & 0.315 & 0.545 \\
\hline p-level Foreign Capital & 0.058 & 0.023 & 0.234 & 0.089 & 0.000 & 0.033 & 0.242 & 0.436 & 0.207 & 0.691 & 0.607 & 0.979 \\
\hline p-level Sector & 0.835 & 0.549 & 0.041 & 0.360 & 0.015 & 0.379 & 0.661 & 0.734 & 0.504 & 0.859 & 0.899 & 0.131 \\
\hline p-level Work Position & 0.008 & 0.000 & 0.727 & 0.280 & 0.332 & 0.122 & 0.000 & 0.001 & 0.007 & 0.186 & 0.129 & 0.232 \\
\hline
\end{tabular}

Source: own processing. 
As it is obvious from the Table 2 each factor affected, to a certain extent, the respondents' attitudes towards the particular items. The most significant influence may be attributed to the seat of the organization (the state), which manifested itself in the existence of statistically significant differences in up to six items out of twelve. Only a little smaller number of statistically significant differences (5) was caused by the factor "respondent's work position". To understand the following text it is necessary to clarify the way of coding the classification characteristics. These are summarized by Table 3 .

Table 3. Classification characteristics of the assigned value

\begin{tabular}{|c|c|c|c|c|c|}
\hline Legal form & $\begin{array}{c}\text { Number } \\
\text { of employees }\end{array}$ & Seat & Sector & $\begin{array}{c}\text { Foreign } \\
\text { capital }\end{array}$ & $\begin{array}{c}\text { Work } \\
\text { position }\end{array}$ \\
\hline 1 - joint stock company & $1-10$ and less & $1-\mathrm{SR}$ & $1-$ primary & $1-$ up to $20 \%$ & $1-$ manager \\
\hline 2 - Ltd. & $2-11$ up to 50 & $2-\mathrm{CR}$ & 2 - secondary & $2-21 \%-40 \%$ & 2 - employee \\
\hline 3 - cooperative & $3-51$ up to 250 & 3 - elsewhere & 3 - tertiary & $3-41 \%-60 \%$ & \\
\hline 4 - other (SHR, trade) & $4-251$ and more & & 4 - quaternary & $4-61 \%-80 \%$ & \\
\hline $5-\operatorname{vos}$ & & & & $5-81 \%$ a more & \\
\hline
\end{tabular}

Source: own processing.

Table 4 summarizes the results of the non-parametric correlations calculated to detect what is the reason behind the statistically significant differences in the respondents' attitudes.

Table 4. Field 1, factor legal form - correlations

\begin{tabular}{llclll}
\hline & & Legal Form & Item 7 & Item 8 & Item 9 \\
\hline Kendall's tau & Legal Form & 1 & $0.132^{* *}$ & $0.134^{* *}$ & $0.138^{* *}$ \\
\hline Spearman's rho & Legal Form & 1 & $0.152^{* *}$ & $0.153^{* *}$ & $0.156^{* *}$ \\
\hline
\end{tabular}

Source: own processing.

There is a highly significant inversely proportional extent of the correlation between items 7, 8 and 9 and the legal form of the company, whose strength is mild. With regard to the numerosity of the occurrence of the individual scale possibilities (possibilities 1 and 2 prevailed) we therefore assume that these possibilities were chosen especially by the respondents working in the limited liability companies, in cooperatives, or the respondents working as tradesmen. The results indicate that the difference in the attitudes caused by the different legal forms exists namely between joint stock companies and the other legal forms. The extent of dependency closeness is relatively low, therefore this statement cannot be considered to be generally true.

Table 5. Field 1, factor number of employees - correlations

\begin{tabular}{llcccc}
\hline & & Number of Employees & Item 1 & Item 3 & Item 5 \\
\hline Kendall's tau_b & Number of Employees & 1 & $0.121^{* *}$ & $0.155^{* *}$ & $0.138^{* *}$ \\
\hline Spearman's rho & Number of Employees & 1 & $0.150^{* *}$ & $0.191^{* *}$ & $0.173^{* *}$ \\
\hline
\end{tabular}

Source: own processing. 
A situation similar to the previous one. Again, it was possible to demonstrate a low extent of the inversely proportional correlation between the individual items (1, 3 and 5) and the number of employees. It is possible to judge that especially the businesses with higher numbers of employees have clearly defined policy of diversity and that these companies, also under the influence of respecting the diversity policy, actively support employing handicapped job candidates, or, as the case may be, job candidates from other ethnicities (mild to medium dependency between items 1,3 and 5).

Table 6. Field 1, factor seat of the company - correlations

\begin{tabular}{lcccccccc}
\hline & & State & Item 1 & Item 2 & Item 6 & Item 7 & Item 8 & Item 10 \\
\hline Kendall's tau_b & State & 1 & 0.06 & $0.107^{*}$ & $0.147^{* *}$ & $0.144^{* *}$ & $0.158^{* *}$ & $0.160^{* *}$ \\
\hline Spearman's rho & State & 1 & 0.068 & $0.120^{*}$ & $0.164^{* *}$ & $0.159^{* *}$ & $0.172^{* *}$ & $0.167^{* *}$ \\
\hline
\end{tabular}

Source: own processing.

The seat of the company had influence on the respondents' attitudes in items $1,2,6,7,8$ and 10 when a statistically significant extent of dependency could be proved in all of the stated cases with the exception of item 1. While the correlation coefficients are positive in all the cases, it is possible to assume that the consensus was mainly manifested by the respondents from Slovakia. This difference may be caused by a higher degree of criticism of the Czech respondents arising from higher awareness concerning diversity and its management. A high level of dependency can be seen between items 7 and 8 (fair treatment of employees regardless of their age or gender).

Table 7. Field 1, factor proportion of foreign capital - correlations

\begin{tabular}{llcccc}
\hline & & Foreign Capital & Item 2 & Item 5 & Item 6 \\
\hline Kendall's tau_b & Foreign Capital & 1 & 0.026 & $0.111^{\star}$ & 0.008 \\
\hline Spearman's rho & Foreign Capital & 1 & 0.032 & $0.140^{\star}$ & 0.009 \\
\hline
\end{tabular}

Source: own processing.

The influence of the proportion of foreign capital was manifested especially in the respondents' attitudes in item 5 (employing job candidates from other ethnicities), where it was possible to prove a statistically significant inversely proportional correlation. It is therefore possible to assume that employing job candidates from other ethnicities is actively supported mainly by companies with a higher proportion of foreign capital and this creates an assumption of assigning the managerial positions to foreign workers from countries where diversity management has been topical for a longer period of time (at least in comparison with the Slovak and Czech Republics).

Table 8. Field 1, factor sector of national economy - correlations

\begin{tabular}{llccc}
\hline & & Sector & Item 3 & Item 5 \\
\hline Kendall's tau_b & Sector & 1 & 0.023 & 0.084 \\
\hline Spearman's rho & Sector & 1 & 0.026 & 0.101 \\
\hline
\end{tabular}

Source: own processing. 
Despite the differences in the respondents' attitudes caused by the influence of working in a company in the relevant sector of national economy it was not possible to prove a statistically significant correlation between this factor and items 3 and 5.

Kruskal-Wallis test proved the existence of statistically significant differences in the respondents' attitudes based on their work position. In other words, different degrees of consensus with statements in items 1, 2, 7, 8 and 9 were expressed by managers on the one hand and by ordinary employees on the other. From Table 9 it is obvious that the correlation coefficients are positive, and this implies that a higher degree of consensus was expressed by managers, which is interesting. The perception of the fair treatment of employees is different with managers and with ordinary employees.

Table 9. Field 1, factor the respondent's work position - correlations

\begin{tabular}{llclllll}
\hline & Work Position & Item 1 & Item 2 & Item 7 & Item 8 & Item 9 \\
\hline Kendall's tau_b & Work Position & 1 & $0.133^{* *}$ & $0.185^{* *}$ & $0.178^{* *}$ & $0.161^{* *}$ & $0.144^{* *}$ \\
\hline Spearman's rho & Work Position & 1 & $0.150^{* *}$ & $0.204^{* *}$ & $0.192^{* *}$ & $0.173^{* *}$ & $0.153^{* *}$ \\
\hline
\end{tabular}

Source: own processing.

\subsection{The field of implementation of diversity management}

Items 13-18 were dedicated to diversity management.

Item 13 The organization provides managers sufficient training for them to cope with issues related to diversity.

Item 14 Managers support open discussion about problems of diversity and equality on the workplace.

Item 15 Managers perceive employees as autonomous individuals.

Item 16 Managers bear in mind diversity issues when assigning tasks and commitments.

Item 17 The scope of work is adapted to the needs of the individual groups of employees.

Item 18 The recruitment of employees is intentionally aimed at raising the level of diversity on the workplace.

As it is obvious from Table 10, the factors "legal form", "number of employees" and "sector of national economy" had no influence or almost no influence on the respondents' attitudes in the field of implementation of diversity management. On the contrary, the seat of the com-

Table 10. Field of implementation of diversity management

\begin{tabular}{lcccccc}
\hline & Item 13 & Item 14 & Item 15 & Item 16 & Item 17 & Item 18 \\
\hline p-level Legal Form & 0.386 & 0.482 & 0.569 & 0.839 & 0.248 & 0.215 \\
\hline p-level Number of Employees & $\mathbf{0 . 0 0 7}$ & 0.307 & 0.222 & 0.612 & 0.240 & 0.385 \\
\hline p-level State & $\mathbf{0 . 0 0 1}$ & $\mathbf{0 . 0 0 5}$ & $\mathbf{0 . 0 0 0}$ & $\mathbf{0 . 0 4 4}$ & $\mathbf{0 . 0 0 4}$ & $\mathbf{0 . 0 4 3}$ \\
\hline p-level Foreign Capital & $\mathbf{0 . 0 0 1}$ & 0.090 & 0.053 & 0.052 & $\mathbf{0 . 0 1 0}$ & 0.065 \\
\hline p-level Sector & 0.202 & 0.065 & 0.189 & 0.290 & 0.233 & $\mathbf{0 . 0 0 0}$ \\
\hline p-level Work Position & 0.056 & $\mathbf{0 . 0 0 1}$ & $\mathbf{0 . 0 1 0}$ & $\mathbf{0 . 0 2 0}$ & $\mathbf{0 . 0 0 5}$ & $\mathbf{0 . 0 1 3}$ \\
\hline
\end{tabular}

Source: own processing. 
pany turned out to be a significant determinant of the respondents' attitudes in all the items. The factor "work position of the respondent" turned out to be significantly influential again.

As it is obvious from Table 11, a higher degree of consensus with the statement that managers are provided sufficient training for them to cope with issues related to diversity was expressed by the respondents in companies with a higher number of employees.

The factor "seat of the company" (Table 12) influenced the respondents' attitudes significantly again (there were different answers with respondents working in companies residing in Slovakia and with those working in Czech companies). Despite the fact that the strength of correlation is only mild, all the correlations are statistically significant. And once again, the Slovaks expressed a higher degree of consensus than the Czechs.

Table 11. Field 2, factor number of employees - correlations

\begin{tabular}{llll}
\hline & & Number of Employees & Item13 \\
\hline Kendall's tau_b & Number of Employees & 1 & $0.126^{* *}$ \\
\hline Spearman's rho & Number of Employees & 1 & $0.160^{* *}$ \\
\hline
\end{tabular}

Source: own processing.

Table 12. Field 2, factor seat of the company - correlations

\begin{tabular}{lcccccccc}
\hline & & State & Item13 & Item14 & Item15 & Item16 & Item17 & Item18 \\
\hline Kendall's tau_b & State & 1 & $0.146^{* *}$ & $0.117^{*}$ & $0.168^{* *}$ & $0.095^{*}$ & $0.158^{* *}$ & $0.102^{*}$ \\
\hline Spearman's rho & State & 1 & $0.169^{* *}$ & $0.136^{*}$ & $0.189^{* *}$ & $0.110^{*}$ & $0.182^{* *}$ & $0.117^{*}$ \\
\hline
\end{tabular}

Source: own processing.

According to the results shown in Table 13 the scope of work of the individual groups of employees is more flexible in companies with a lower extent of foreign capital, which is in mild contrast with the existing results because (as has also been stated above) especially a higher extent of foreign capital creates prerequisites for "import of know-how" and it is just the know-how that helps deal with issues of diversity management on the workplace, which is, among other things, one of the important topics of management of human resources.

Table 13. Field 2, factor proportion of foreign capital - correlations

\begin{tabular}{llccc}
\hline & & Foreign Capital & Item13 & Item17 \\
\hline Kendall's tau_b & Foreign Capital & 1 & -0.032 & $0.107^{*}$ \\
\hline Spearman's rho & Foreign Capital & 1 & -0.043 & $0.130^{*}$ \\
\hline
\end{tabular}

Source: own processing.

The factor "sector of national economy" (Table 14) influenced the respondents' attitudes in item 18 (intentional raise of the level of diversity on the workplace). The extent of dependency is statistically significant and the correlation coefficient has a positive value. Based on this result it is possible to judge that the intentional raise of the level of diversity on the workplace is preferred mainly by the companies from the primary and secondary sector. 
Table 14. Field 2, factor sector of national economy - correlations

\begin{tabular}{llcc}
\hline & & Sector & Item18 \\
\hline Kendall's tau_b & Sector & 1 & $0.111^{*}$ \\
\hline Spearman's rho & Sector & 1 & $0.133^{*}$ \\
\hline
\end{tabular}

Source: own processing.

Table 15. Field 2, factor working position of the respondent - correlations

\begin{tabular}{llcccccc}
\hline & Work Position & Item14 & Item15 & Item16 & Item17 & Item18 \\
\hline Kendall's tau_b & Work Position & 1 & $0.157^{* *}$ & $0.125^{*}$ & $0.114^{*}$ & $0.136^{* *}$ & $0.122^{*}$ \\
\hline Spearman's rho & Work Position & 1 & $0.178^{* *}$ & $0.138^{*}$ & $0.129^{*}$ & $0.154^{* *}$ & $0.139^{*}$ \\
\hline
\end{tabular}

Source: own processing.

Kruskal Wallis test proved the existence of statistically significant differences in the attitudes of the respondents based on their working position in items 14-18 (Table 15). All the measured correlations between the given items and the classifying variable itself are statistically significant. The strength of dependency closeness is weak, the correlation coefficients are positive. It is possible to assume that (similarly to the preceding case in field 1) managers had a bigger tendency to express a noticeably positive attitude, while this was much less noticeable with ordinary employees.

\subsection{The field of benefits resulting from implementing diversity management}

The remaining items of the questionnaire (19-25) fell into the field of benefits resulting from implementing diversity management:

Item 19 Diversity of employees provides a possibility of identifying customers' needs better. Item 20 Diversity of employees provides the employer with a wide scope of abilities and skills.

Item 21 Diversity of employees provides the employer with a possibility of selecting better quality employees.

Item 22 Diversity of employees brings with itself a better possibility of innovation thanks to a variety of new ideas.

Item 23 Diversity of employees enriches the teamwork and makes it more interesting.

Item 24 Diversity of employees improves the organization image.

Item 25 Diversity of employees improves the atmosphere on the workplace.

The Table 16 illustrates the variability of respondents in perceiving benefits.

The only two factors (Table 17) that affected the attitudes of the respondents in the field of perceiving benefits resulting from implementing diversity management were the seat of the company (item 27) and the proportion of foreign capital (items 22-25). The legal form of the company, number of employees, sector of national economy and employee's working position did not affect the respondents's attitudes.

The extent of dependency closeness in item 22 (possibility of innovation) is not statistically significant. 
Table 16. Field of benefits resulting from implementing diversity management

\begin{tabular}{lccccccc}
\hline & Item 19 & Item 20 & Item 21 & Item 22 & Item 23 & Item 24 & Item 25 \\
\hline p-level Legal Form & 0.874 & 0.856 & 0.984 & 0.274 & 0.282 & 0.452 & 0.871 \\
\hline p-level Number of Employees & 0.085 & 0.548 & 0.164 & 0.511 & 0.331 & 0.092 & 0.239 \\
\hline p-level State & 0.842 & 0.610 & 0.055 & $\mathbf{0 . 0 3 7}$ & 0.227 & 0.604 & 0.555 \\
\hline p-level Foreign Capital & 0.388 & 0.060 & 0.333 & $\mathbf{0 . 0 1 4}$ & $\mathbf{0 . 0 1 1}$ & $\mathbf{0 . 0 2 4}$ & $\mathbf{0 . 0 0 3}$ \\
\hline p-level Sector & 0.182 & 0.677 & 0.801 & 0.778 & 0.372 & 0.238 & 0.873 \\
\hline p-level Work Position & 0.332 & 0.118 & 0.917 & 0.503 & 0.878 & 0.783 & 0.425 \\
\hline
\end{tabular}

Source: own processing.

Table 17. Field 3, factor seat of the company - correlations

\begin{tabular}{llcc}
\hline & & State & Item 22 \\
\hline Kendall's tau_b & State & 1 & 0.078 \\
\hline Spearman's rho & State & 1 & 0.087 \\
\hline
\end{tabular}

Source: own processing.

Table 18. Field 3, factor proportion of foreign capital - correlations

\begin{tabular}{llccccc}
\hline & & Foreign Capital & Item 22 & Item 23 & Item 24 & Item 25 \\
\hline Kendall's tau_b & Foreign Capital & 1 & -0.028 & -0.037 & -0.059 & -0.017 \\
\hline Spearman's rho & Foreign Capital & 1 & -0.032 & -0.044 & -0.073 & -0.020 \\
\hline
\end{tabular}

Source: own processing.

Similarly to the case of the company seat, in the case of proportion of foreign capital the statistical significance of the correlation was not vindicated either. Despite this fact it is obvious from Table 18 that the difference in perceiving benefits mainly exists in companies with a higher extent of foreign capital.

\section{Conclusions and discussion}

It is possible to state that some findings are in harmony with the expectations resulting from the theory but even from the existing practical cases of implementing diversity management in organizations. Other findings did not live up to the expectations. The most significant findings gained by means of the research survey can be summarized as follows:

\section{The field of inclusion and justice}

- The field of inclusion and justice is generally perceived more positively by the respondents from Slovakia than those from the Czech Republic. The difference was noticed most clearly with the items concerning the policy of employing women, fair treatment of employees regardless of their age, gender and religion. Owing to the fact that the existing conditions on the labour market as far as diversity is concerned do not show much difference between the two countries the above finding may seem surprising. For instance the gender pay gap has been above the level of $20 \%$ in Slovakia over the past three years (2008-2010) and in the 
Czech Republic above 25\% (Eger et al. 2012), employment of older workers (55-64 years of age) was $46.5 \%$ in the Czech Republic in 2010, in Slovakia it was almost $40.5 \%$ (Eger et al. 2012). The assessment of the respondents (positive or negative) is obviously affected by different values, norms and attitudes reflecting the culture (Brunet-Thorton, Bureš 2012) of both the countries in general but also by the organisation culture in the sense of how people relate to one other (Demir et al. 2011) The respondent's own personal experience also plays a significant role.

- Diversity policy is clearly defined especially in companies with more than 250 employees (the so called large companies, (Gozora 2005)). This finding is not surprising owing to the fact that a higher number of employees naturally creates a precondition for growing diversification of workforce (diversified on the basis of age, gender or ethnicity, (Süß, Kleiner 2008)). As a result, the existence of the diversified workforce creates pressure and needs for the management of the organisation to deal with the issues of diversity management.

- The opinions of the respondents concerning the fair treatment of employees regardless of their age or gender (fair treatment in general) vary depending on their work positions. In comparison with the ordinary employees the managers perceive this field in a more positive way. It is only natural, even though only to a certain extent, that managers tend to assess their work positively and are reluctant to admit openly that there are situations they are not in command of and they rather declare the given field does not pose any problem for them. If, however, the problem is not identified, it cannot be solved. On the other hand, the negative perception of the situation from the side of the employees may be influenced by the fact that they have already met a certain form of injustice directly (Ceylan, Sulu 2011) or that a part of their experience is mediated (they have heard about a given case).

- The willingness to employ the candidates from other ethnicities is typical mainly of companies with a higher proportion of foreign capital. It is natural in those companies that procedures from the field of diversity management are applied as they are common in the countries where the capital comes from. The given finding reflects the experience that the foreign companies are more aware, with regard to the ever more competitive environment, of the necessity to employ more diverse workforce, i.e. the workforce from other ethnicities and thus they apply the diversity policy in a larger extent. On the other hand, the reluctance of companies in the Czech and Slovak Republics to employ the candidates from other ethnicities is, to a large extent, affected by the existing economic, political and legislative situation in both the countries. Nevertheless it is necessary to realize that with regard to the latest developments on the labour market the Czech and Slovak economies will need those employees in the following years.

\section{The field of implementation of diversity management}

- The field of implementation and justice is perceived more positively by the respondents from Slovakia than those from the Czech Republic. More significant differences also occurred in the field of work position as here managers showed a tendency to judge the individual items more positively than ordinary employees.

- Sufficient training aimed at managing problems related to diversity is provided by companies with a higher number of employees as opposed to smaller companies. The given statement reflects the above findings but also the fact that the attitude of companies towards training of 
employees is, to a large extent, affected by the company size because the higher the number of employees the bigger the proportion of companies providing training for their employees. It is necessary to realize that effective diversity management assumes having necessary competences. Especially the managers may have capabilities concerning knowledge management (Jermár 2012) and diversity management. Education focusing on cultural diversity should be a significant element of the strategy of the diversity management in organisation. In the time of great cultural diversity it is important to understand that different communities have different rules, approaches and requirements (Semrádová, Kacetl 2011). Unfortunately, in the current situation, many companies reduce the amount of money spent on their employees including education and training activities (Elexová 2011).

- The scope of work is more adapted to the needs of individual employment groups in companies with a lower proportion of foreign capital, which contradicts slightly with the existing results because (as is stated above) it is just the higher proportion of foreign capital that creates the preconditions for importing the "know-how", which is also necessary for dealing with the problems of diversity on the workplace as an issue important for the appropriate management of human resources. A surprising fact here was that the willingness to adapt the content of the scope of work was manifested mainly by staff from companies with a lower number of employees.

\section{The field of benefits resulting from implementing diversity management}

- Perceiving benefits resulting from implementing diversity management is relatively universal. The only factors showing differences were the factors of the company seat and the proportion of foreign capital. Despite the above stated agreement on the benefits resulting from the diversified workforce there is still an unsolved problem of quantification of the benefits, and how they project themselves in the performance of the individual company even though some partial studies focusing on the given topic have already been carried out (European commission 2008; Hubbard 2004b, 2011; Lockwood 2005). If, for example it was possible to provide precise calculations of savings in the costs caused by reducing the factor of fluctuation thanks to increasing the work morale and the enthusiasm of employees, there would be much more willingness from the side of businessmen to deal with issues like that.

We assume that our research survey identified, at least partially, the existing state of implementing the concept of diversity management in organizations in the Czech Republic and in Slovak Republic. We are, at the same time, aware of the fact that some fields we focused on in our research require further in-depth research in the future.

\section{Acknowledgment}

The paper is a part of the research project Diversity management, comparison, the best practices of Visegrad countries, Visegrad Fund, No 21110193. 


\section{References}

Bedrnová, E.; Nový, I. 2007. Psychologie a sociologie řizení [Psychology and Sociology of Management]. Prague: Praha Management Press.

Brunet-Thorton, R; Bureš, V. 2012. Cross-cultural management: establishing a Czech benchmark, $E \& M$ Ekonomie a Management 15(3): 46-62.

Ceylan, A.; Sulu, S. 2011. Organizational injustice and work alienation, E\&M Ekonomie a Management 14(2): 65-78.

Demir, C.; Unnu, N. A. A; Erturk, E, 2011. Diagnosing the organizational culture of Turkish pharmaceutical company based on competing values framework, Journal of Business Economics and Management 12(1): 197-217. http://dx.doi.org/10.3846/16111699.2011.555451

Durska, M. 2009. Diversity management: key concepts, Kobieta i Biznes 1(4): 36-41.

Eger, L.; Egerová, D.; Předotová, J.; Petrtyl, J.; Mužík, J.; Tureckiová, M.; Krištofová, Z.; Kubát, M.; Veteška, J.; Lančarič, D.; Procházka, A. 2009. Diverzity management [Diversity Management]. Praha: Česká andragogická společnost.

Eger, L.; Egerová, D.; Jiřincová, M.; Petrtyl, J.; Plevný, M.; Bitterová, M.; Lančarič, D.; Peterka, A.; Pisoňová, M.; Savov, R.; Hajós, L.; Czeglédi, C.; Cseh Papp, I.; Rozwadowski, J.; Wójcik, J. 2012. Diversity management comparison, the best practices of Visegrad countries. Plzeň: Nava.

Egerová, D. 2012. Diversity management as a crucial issue of the management in the $21^{\text {st }}$ century, Problems of Management in the 21 $1^{\text {st }}$ Century 2(3): 5-7.

Elexová, G. 2011. Human resources development under the conditions of the global crisis, $E \& M$ Ekonomie a Management 14(3): 46-55.

European Commission. 2008. Continuing the diversity journey. Luxembourg: Office for Official Publications of the European Communities. http://dx.doi.org/10.2767/59706

Gozora, V. 2005. Podnikový manažment [Enterprise Management]. Nitra: SPU v Nitre.

Hebák, P. 2005. Vícerozměrné statistické metody 3 [Multivariate Statictical Methodsnterprise Management 3]. Praha: Informatorium.

Hubbard, E. E. 2004a. Diversity management. Amherst: HRD Press.

Hubbard, E. E. 2004b. The diversity scorecard: evaluating the impact of diversity on organizational performance (improving human performance). Burlington: Butterworth-Heinemann.

Hubbard, E. E. 2011. The diversity scorecard: evaluating the impact of diversity on organizational performance (improving human performance). Burlington: Butterworth-Heinemann.

Ilmakunnas, P.; Ilmakunnas, S. 2011. Diversity at the workplace: whom does it benefit?, Economist-Netherlands 159(2): 223-255. http://dx.doi.org/10.1007/s10645-011-9161-x

Jermáŕ, M. 2012. Knowledge potential development of firms-inspirations for human resources management, E\&M Ekonomie a Management 15(2): 85-93.

Jurčová, D. 2005. Slovník demografických pojmov [Dictionnary of demographic terms]. Bratislava: Edícia Akty.

Keil, M.; Amershi, B.; Holmes, S.; Jablonski, H.; Lüthi, E.; Matoba, K.; Plett, A.; Unruh, K. 2007. Diversity management, vzdělávací manuál [Training manual for diversity management] [online], [cited 04 November 2012]. Available from Internet: http//ec.europa.eu/social/BlobServlet?docId=1474\&langId=cs

Lokwood, N. R. 2005. Workplace diversity: leveraging power of difference for competitive advantage, HR Magazine 50(6):1-10.

Pavelka, F.; Klímek, P. 2000. Aplikovaná statistika [Applied statistics]. Zlín.

Rimarčík, M. 2007. Štatistika pre prax [Statistics for practice]. Vydavatestvo: Jozef Rimarčík. 
Risberg, A.; Soderberg, A. M. 2008. Translating a management concept: diversity management in Denmark, Gender in Management: an International Journal 23(6): 426-444. http://dx.doi.org/10.1108/17542410810897544

Thomas, R. R. 2006. Building on the promise of diversity. New York: Amacom.

Thomas, R. R. 2010. Worldclass diversity management: strategic approach. San Francisco: Berrett-Koehler Publishers, Inc. 2.

Semrádová, I.; Kacetl, J. 2011. Ethics in the future manager's professional training, E\&M Ekonomie a Management 14(2): 79-89.

Süß, S.; Kleiner, M. 2008. Dissemination of diversity management in Germany: a new institutionalist approach, European Management Journal 26(1): 35-47. http://dx.doi.org/10.1016/j.emj.2007.10.003

Sweetman, C. 2004. Gender, development and diversity. Oxford: Oxfam Publishing.

Dana EGEROVÁ. PhD, Assistant Professor at the Department of Business Administration and Management, Faculty of Economics, University of West Bohemia in Pilsen. Research interests: human resource management, diversity management, talent management, information technology in employee training and development.

Milena JIŘINCOVÁ. PhD student at the Department of Business Administration and Management, Faculty of Economics, University of West Bohemia in Pilsen. Research interests: diversity management, human resource management.

Drahoslav LANČARIČ. PhD, Assistant Professor at the Department of Management, Faculty of Economy and Management, Slovak University of Agriculture in Nitra. Research interests: corporate planning, diversity management, operations management.

Radovan SAVOV. PhD, Assistant Professor at the Department of Management, Faculty of Economy and Management, Slovak University of Agriculture in Nitra. Research interests: strategic management, diversity management, corporate planning. 